\section{Research Square}

Preprints are preliminary reports that have not undergone peer review.

They should not be considered conclusive, used to inform clinical practice, or referenced by the media as validated information.

\title{
Demographic Characteristics of Population With Affinity for Wetland Settlements in Ghana.
}

\author{
Victor Kwesi Quagraine ( $\nabla$ victor3q@yahoo.com ) \\ Kwame Nkrumah University of Science and Technology https://orcid.org/0000-0001-5879-0875 \\ Joy Ofori-Konadu \\ Kwame Nkrumah University of Science and Technology \\ Michael Osei Asibey \\ Kwame Nkrumah University of Science and Technology
}

Research Article

Keywords: Wetlands, Wetland settlements, Demographic characteristics, Ghana, Policies.

Posted Date: June 29th, 2021

DOI: https://doi.org/10.21203/rs.3.rs-559613/v1

License: (1) This work is licensed under a Creative Commons Attribution 4.0 International License. Read Full License 


\section{Abstract}

Wetlands all over Africa are being unsustainably reclaimed due mostly to high rate of population growth, urbanization and rising poverty. Despite having numerous ecosystem services that are of great benefit to humanity, wetlands are among the most threatened ecosystems due to destructive anthropogenic activities. However in order to sustainably use and manage wetlands in Africa, more data must be made available for policy formulation and decision-making. Africa lacks sufficient, basic and accurate data on population demographics that have affinity to wetland settlement. Research is needed to provide this scientific basis in Africa. This study investigates the demographic characteristics of the population with affinity to wetland settlements in Ghana to also contribute in filling in the gap identified by the National Environmental Action Plan of Ghana. The questionnaire survey approach was used with a sample size of 318 residents along two rivers in Kumasi. The demographic information that characterizes wetland settlers as revealed by this study include, low incomes, high rate of unemployment and poverty and low patronization of formal education. The high percentage of those with Senior High School certificates holders at the wetlands was also alarming. The settlers were mostly young and active. However, it was also found that data on the gender, ethnicity and religion of wetland settlers must be better determined at individual localities.

\section{Background}

The main objective of the study was to investigate the demographic characteristics of the population that have affinity for wetland settlements in Ghana to establish some basic facts and data needed for policy formulation and decision-making. Wetlands are defined to include swamps, bogs, marshes, fens, peatlands, floodplains and coastal areas (Zedler and Kercher, 2005). They also include edge habitats of plants and animals along rivers, streams and lakes (Lomnicky et al., 2019). Their sources of water include rains, surface flow, springs and floods (Sah and Heinen, 2001). All continents have a network of temporary, perennial and permanent wetlands along their coasts, rivers, lakes, streams and in some depressions. Wetlands are mostly undeveloped areas which can easily be converted into agriculture lands and industrial development areas (Wood et al., 2013; Hachigonta et al., 2013; Rebelo et al., 2010). They make up about $5-8.5 \%$ of the world's land surface, that is about 7-10 million $\mathrm{km}^{2}$ (Mitsch and Gosselink 2007). The extent of wetlands coverage in Africa lacks accurate data (Schuijt, 2002) however, it is estimated to be between $1 \%$ (World Conservation Monitoring Centre (WCMC), 1992) and 16\% (Koohafkan, 1998). Zedler and Kercher (2005) also estimate it to be $2 \%$, while Rebelo, et al. (2009) estimate $4.7 \%$ for sub-Saharan Africa, which corresponds to the 228 million hectares of Bergkamp et al. (2000) and Matthew and Fung (1987).

Wetlands were considered as swamps lands that bred diseases, impeded overland travel and the production of food and fiber and therefore not useful for human survival (Tebeau, 1980). They were regarded mostly as wastelands, unpleasant and unhealthy environments (Patrick Jr., 1994), and obstacles to development and therefore must be destroyed to make available the land for beneficial purposes such as agricultural, urban and industrial uses (Tebeau, 1980; Patrick Jr., 1994). However, since the last century, society's view about wetlands have changed considerably, especially with better and in-depth knowledge about their values. There is more interest in their protection, management and preservation (Dahl and Allord, 1982). They are considered as highly fertile plain landscape topography (Foziah, 2009) which have played important roles in the history of human development. The fertile plains of the rivers Nile, Euphrates, Tigris and Indus propelled the economic bases that produced the high cultures of the Egyptians, Sumerians and the Harappas about 5000 to 4000 years ago (Hammerton, 1972; Boule, 1994), and according to the Ramsar Convention (2018), wetlands provide critical support to seven (7) of the seventeen (17) main Sustainable Development Goals defined by the United Nations. Wetlands exhibit a wide range of functional attributes that benefits humanity, including water purification and storage, shoreline protection, processing of nutrients, assurance of food security and support of biodiversity for animals and plants (Ramsar Convention, 2018; Millennium Ecosystem Assessment, 2005). They contain 10-20\% of the global terrestrial carbon (Mitsch and Gosselink, 2007), retain sediments and toxicants (Kent, 2000) and serve as ecological balance systems (Root et al., 2003). Wetlands also provide construction materials, serve as basis for rich cultural tradition (van Dam et al., 2011) and other economic activities (Wood et al., 2013; Hachigonta et al., 2013; Rebelo et al., 2010). Other functions include the provision of fuelwood, medicinal resources, genetic resources, transport systems, energy, climate stabilization, and storage and recycling of organic waste (De Groot, 1992; Roggeri, 1995).

Since 4000BC, during the Neolithic times, wetlands have been sites for subsistence settlements (Kooijmas, 1987). Early human beings settled close to water bodies and their wetlands to benefit from their fresh water, natural water treatment, food, fibre and 
construction materials. In fact, many of the world's urban cities are built along rivers and their wetlands (Kingsford et al., 2016) and many local communities in almost all parts of the world depend on the wetlands for their many functional services (Morrison et al., 2013; van Dam et. al., 2011; Ozesmi and Bauer, 2002). However, increasing population has resulted in extensive wetland reclamation for agriculture and urban construction and expansion activities (Wang and Ma, 2016). Other human activities that negatively affect wetlands include airborne particulate fallouts (Lomnicky et al., 2019), construction of flood control systems including levees, dams and wells (Fretwell et al., 1996), and water management and land drainage projects (Dahl et al., 1991). Wetland functions can be overwhelmed in areas of heavy human activities (Mitsch and Gosselink, 2000) and since these activities have always exploited the productivity of wetlands, their overexploitation has become an increasing problem (Stone, 2003). Wetlands are under increasing threat (Mafabi, 2000; Owino and Ryan, 2007) and despite their importance, globally they are shrinking at a rate faster than other ecosystems, especially in developing countries (Nicholls, 2004) mainly due to human activities (Johnson, 1994; Millennium Ecosystem Assessment, 2005: Jacob, et al 2014). Researchers have different estimates for the extent of global wetland depletion. Nicholls (2004) estimates it as 50\% since 1900, whereas Hu et al. (2017) put the global loss at 33\% since 2009. Kingsford (2016) asserts that about $70 \%$ of the world's wetlands is already destroyed or impaired and based on existing data in several regions, Davidson (2014) also asserts that not only is $87 \%$ of the world's wetlands degraded since 1700 but also these degradations occurred mostly in the 20th and early 21 st centuries.

Since wetlands are among the world's most important productive ecosystems (Zedler and Kercher, 2005; Wang and Ma, 2016) and the human benefits that accrue from maintaining them greatly outweighs converting them to other land uses such as agriculture (Maclean, et al., 2011; Schuyt, 2005), they must be protected or be used sustainably (Sabic et al., 2013) at worse. Considering the current rate of wetland depletion, especially in Africa (Quevauviller, 2009), there is the need to provide sound policies, structures and guidelines to aid its protection, management, conservation and sustainable use. Many African countries are signing the Ramsar Convention, which also indicates a growing interest and commitment to sustainable wetland management (Schuijt, 2002). However, the future of wetlands in Africa lies in the hands of sound policies (Kabii, 1996). Many tropical countries still require national wetland policies and structures to enforce their protection and sustainable management (Junk, 2002). For efficient protection of wetlands, there must be provision of data to bridge science and policy (Cools et al., 2013). There is insufficient data for policy-decision makers in wetland management (Martinez-Harms et al., 2015; Foster et al., 2015). Laws, statutes and policies for the determination, delineation, regulation, restoration, acquisition, incentives and disincentives and permits to use wetlands must be backed by scientific data (Kent, 2000). The need for data and information to support wetland management is multi-scalar: global, regional, national, local to guide policy formulation and decision making (Finlayson and Spiers, 1999). The Millennium Ecosystem Assessment also underscores the importance of the availability of a comprehensive information base for the understanding of the status and trends, values and major drivers of change of wetlands (Finlayson, et al., 2005; Wetlands International, 2005). Though the challenges with regard to the provision of data and information for understanding wetlands prevail on all continents (Cools et al., 2013), the scarcity is worse in much of the developing world where encroachment and degradation proceed at an unprecedented rate (Quevauviller, 2009). This paper contributes to the provision of data for policy-decision making to facilitate sustainable wetland management in Ghana (Anderson, 1998) by investigating the demographic characteristics of the population with the affinity for wetland settlement in the country.

\subsection{Characteristics of Population with Affinity for Wetland Settlement}

A major reason given by Schuijt (2002) for the reclamation and use of wetlands in developing countries is the rising poverty, since many who settle on wetlands are from poor areas (Sabic et al., 2013). Infield (1988), Newmark et al. (1993) and McGregor (1995) are also of the view that poorer people are more dependent on natural products such as wetlands. For Badola (1997), it is part of the tradition and culture of people of lower socio-economic strata to use natural resources such as wetlands. In other words, mostly, the economically marginalized depend on wetland resources for their livelihood (Ozesmi, 1999) since they are mostly unskilled or unqualified workers (Sabic, 2013). The poorer status of those who have affinity for wetland settlement is reflected in the higher unemployment rates (Foziah, 2009; Ozesmi, 1999; Tyler, 2011) and low paid jobs (Tyler, 2011; Pattison et. al., 2011) prevalent at these settlements. These jobs are mostly in the primary sector including fishing, grazing, reed harvesting (Ozesmi and Bauer, 2002), agriculture and labor-class works (Foziah, 2009) and temporary service-based employment (Tyler, 2011). Wetland settlers are mostly part of the local population who depend on the nearby wetland for food and other services (Morrison et al., 2013; Ozesmi and Bauer, 2002), and who usually have lower educational background since literate population has lower dependency on wetland resources (Foziah, 2009). Those who reside at wetlands are mostly young and active (Tyler, 2011).

Page 3/16 


\subsection{Wetlands in Ghana}

Wetlands constitute about $10 \%$ of the Ghana's total land surface, comprising marine/coastal, inland, and man-made systems (Ministry of Lands and Forestry 1999). Until recently, wetlands were considered as "waste lands" and breeding grounds for mosquitoes in Ghana. As such, they were dredged to facilitate water drainage, reclaimed for socio-economic activities and used as dumping grounds for wastes. However, the Ministry of Lands and Forestry Ghana (MLFG) in June 1999 launched the National Land Policy which precluded practices such as physical draining of wetland water, the draining of water courses of wetlands and unapproved human settlements and anthropogenic activities on wetlands (Republic of Ghana, 1999). Moreover, since 1971, when the Convention on Wetlands of International Importance (Ramsar Convention, 1971) came into force, more interests have been shown in Ghana about wetlands. In the early 1990s, the National Environmental Action Plan (NEAP) of Ghana was launched by the then Environmental Protection Council (EPC). The program, which was sponsored by the World Bank and the United Nations Environment Program was to concentrate on areas of environmental concern to the government and people of Ghana (Government of Ghana (GoG), 1994). NEAP covered all aspects of natural resource use in Ghana, including wetland ecosystems. The third of the NEAP's seven research objectives focused on the assessment of the socio-economic conditions of wetland settlements including demographic characteristics (Anderson, 1998). However, much of the research activities in wetlands concerning Ghana has concentrated on mapping of wetlands (such as in Nyarko, 2007; Gumma et al., 2009; Nsor and Obodai, 2014; Adade et al., 2017; Ekuma et al., 2020), health condition and environmental impact of wetlands (Ryan et al., 2000; Attuquayefio and Gbogbo, 2001; Opoku, 2013; Kumi et al., 2015) and wetland management (Armah, 1993; Asomani-Boateng, 2019). Few researches included some demographic characteristics (such as in Opoku, 2013 and Kumi et al., 2015). Thus this study focused mainly on investigating the demographic characteristics of the population that have affinity for wetland settlement, not only to contribute in filling the gap identified by the NEAP (Anderson 1998) but more importantly to provide data to facilitate policy-decision making about wetlands in Ghana.

\section{Materials And Methods}

\subsection{Study Area}

Kumasi was chosen for the research, not only because of its many rivers and streams in its urban and forest environment, but importantly, most of the research on wetlands in Ghana concentrate on the coastal wetlands including Armah (1993), Ryan and Ntiamo-Baidu (2000), Attuquayefio (2001), Adade et al. (2017) and Ekuma et al. (2020). The few wetland researches conducted in the hinterland of Ghana are also concentrated in the northern part of Ghana and do not focus on demographic characteristics, including Nyarko (2007) on mapping the White Volta, Nsor and Obodai et al. (2014) on seasonal variation of bird diversity and Gumma et al. (2009) on rice cultivation. Kumasi, the study area, is both the capital of the Ashanti Region, one of the 16 Regions in Ghana (Figure 1), and the second largest city in Ghana after Accra, the country's capital and largest city.

Kumasi is considered the commercial and transportation hub of the country. Its land area is about $214.3 \mathrm{~km}^{2}$ and has a population of $1,730,249$ with 826,479 males and 903,770 females (Ghana Statistical Service, 2014). The city continues to urbanize at a rate of $5.47 \%$, encompassing about 90 suburbs or neighborhoods, many of which were absorbed through urbanization (Nimura and Eisen, 2010). It is located within latitudes $6.35^{\circ} \mathrm{N}$ and $6.40^{\circ} \mathrm{N}$ and longitudes $1.30^{\circ} \mathrm{W}$ and $1.35^{\circ} \mathrm{W}$ and lies about 300 meters above sea level. It is situated in the forest zone of Ghana and has a tropical wet and dry type of climate with high temperatures for most of the year. The average temperature is $26^{\circ} \mathrm{C}$, the average humidity is $85 \%$ and total annual precipitation is about $1,684.7 \mathrm{~mm}$ (World Weather, 2019). As confirmed by GSS (2014), the city is enriched with a number of major wetlands, including rivers and streams. The notable rivers are the Wiwi, Subin, Aboabo, Owabi, Sisai, Oda, Nsuben, Suntre, Kwadaso, Asuoyeboa as shown in Figure. 2.

Subin and Wiwi rivers were purposively selected for this study due to the fact that they are among the most important wetland sites of ecological, landscape and social interest, (Abdul-Razak, 2012), and also very much depended on by several communities (ObiriDanso et al., 2005; GSS, 2014; Forkuor, 2010; Owusu-Ansah et al., 2016). The Subin river flows from the north of Kumasi towards the south through the city centre or the Central Business District (CBD) and merges with the Oda river at Asago (Dickson and Benneh 1980). The suburbs or neighborhoods through which the river Subin flows are Bantama, Kejetia, Fante New Town, Asafo, Asokwa and Kaase (Obiri-Danso et al., 2005) with an estimated total population of 2,130 (GSS, 2014). The Wiwi river also flows from the north of Kumasi and joins Sisai river (Dickson and Benneh 1980). It passes through the neighborhoods of Kentinkrono, Wiwiso, 
Amangoase, Kwame Nkrumah University of Science and Technology (KNUST) campus, Ahinsan, Atonsu and Gyinaase with an estimated total population of 1,720 (GSS, 2014).

\subsection{Data Collection Technique and Analysis}

The mixed method approach was used, namely the qualitative and quantitative approaches. The qualitative method comprised the literature reviewed which served as the theoretical foundation to the study. Through the literature, some of the demographic variables including gender, age, education, occupation, marital status, ethnicity/tribe and length of stay were adopted from Opoku (2013) and Kumi et al. (2015) to help design the questionnaire. Other demographic variables used were religion, income and type of households. The quantitative approach comprised questionnaire survey. The respondents were randomly selected from the residents living along the Wiwi and the Subin rivers. The distribution of questionnaire was done within the 300 meters (330 yards) on both sides of the rivers established as green-belts during the colonial era and therefore prohibited from habitation (Curtin, 1992; Quagraine, 2011). With study area total population estimates of 1,720 and 2,130 along the Wiwi and Subin rivers respectively, sample sizes of $10 \%$ (Asamoah-Gyimah and Duodu, 2007) were used for the collection of data. Out of the 172 questionnaires for Wiwi and 213 for Subin distributed, 138 and 180 respectively were rightly completed, returned and used for the study. The questionnaire data was analysed using a quantitative method with the aid of the Statistical Package of Social Science (SPSS). The data was first compared to the current demographic distribution data of the Ashanti region (AR) and Ghana as a whole (GSS, 2012) and data sourced from literature for possible similarities and differences that would be important for policy-decision making.

\section{Results And Discussions}

\subsection{Gender Distribution}

Table 1 shows a dominance of female presence in the data for Ghana, Ashanti region (AR), Wiwi and Subin rivers. However, its intensities are revealed along the wetlands of Wiwi (55.8\%) and Subin (58.9\%), as compared to the $51.1 \%$ and the $51.6 \%$ of Ghana and the AR respectively. The male distribution is the reverse of the females'. While this result confirms Pattison et al. (2011), it also differs from Tyler (2011), Opoku (2013) and Kumi et al. (2015) where male dominance is revealed. The result suggests that for policy-decision making, gender data may not be generalized but may be sourced at the individual localities.

\subsection{Age Distribution}

Whereas the age groups 20 s and 30 s have higher scores in both the AR (36.0\% and $25.2 \%)$ and Ghana (34.7\% and $24.6 \%)$ respectively, the age group with the highest scores along the rivers was the age group 40s: Wiwi (39.9\%) and Subin (61.6\%). Nevertheless, the concentration of the younger and active ages of 20s, 30s ,40s was similar along the rivers (Wiwi and Subin) and also in AR and Ghana. This finding agrees with Kumi et al. (2015) where the same age groups (20s, 30s, 40s) scored higher among the respondents and Tyler (2011) where mostly young people (18-64 years) constituted $62 \%$ of the population. For policy purposes, it must be noted that, though wetlands attract young and active population, it is the more matured ones (40s) that are more prevalent.

\subsection{Educational Background}

Table 3 shows higher percentages of Senior High School (SHS) certificate holders along the rivers (Wiwi 39.86\% and Subin 21.0\%) and those with no formal education (Wiwi, 31.9\% and Subin 52.8\%). This finding confirms Opoku (2013) where those with 'no formal education' were the highest, followed by SHS/ Secondary Certificate holders. That wetlands are populated with illiterate population is attested by Foziah (2009), but the situation becomes alarming when the data for Wiwi (31.9\%) and Subin (52.8\%) is compared to those of AR (2.2\%) and Ghana (2.9\%). For policy-decision making, it is important to note that, wetlands are mostly populated with those without formal education, and this phenomenon poses problems since illiterates may consider wetlands to be wastelands that must be converted into other 'profitable' uses such as subsistent farming or into whatever one likes (Tebeau, 1980; Patrick Jr., 1994). In Kumi et al. (2015), those with SHS/Secondary School certificate holders had the highest concentration along wetlands, like the high percentage revealed at the Subin river. The proliferation of SHS Certificate holders can also pose problems. Unable to continue their formal education, SHS Certificate holders would have to be looking for jobs which currently in Ghana are difficult to find. As a consequence, they may feel comfortable to settle on the cheap or free lands along wetlands to engage in subsistent jobs that destroy wetland resources. This finding is crucial for policy-decision making since this phenomenon may introduce new 
demographic distribution along wetlands with the rapidly increasing numbers of the SHS certificate holders coming from the recently introduced free SHS education in Ghana.

\subsection{Occupation}

As shown in Table 4, the most prevalent occupation along the two wetlands was self-employment (Wiwi, 39.9\% and Subin, 38.0\%) in various small and medium scale endeavours (Opoku 2013). This finding is in consonance with, but at higher percentages for both the AR (73.3\%) and Ghana (75.4\%). However, along the wetlands, unemployment not only came second but had high rates of $23.91 \%$ along Wiwi and $47.0 \%$ along Subin rivers compared to AR (4.5\%) and Ghana (3.6\%). Other studies have also identified the economically marginalized as those who mostly depend on wetland resources including Ozesmi (1999), Foziah (2009) and Pattison et al. (2011). The concentration of the unemployed along the rivers (wetlands) may be due to the presence of free or cheap land and building materials that can be used to raise cheap shelters to live in as one searches for a job in the city.

\subsection{Marital Status}

Though the married had higher percentages at Wiwi $(79.71 \%)$ and at Subin $(70.5 \%)$ as shown in Table 5, the finding reflects the general demographic characteristics of both AR (51.9\%) and Ghana (55.1\%). It also agrees with Kumi et al (2015) where the married were in the majority and the divorced and widows were in the minority. Neither wetland registered the divorced nor the separated among the respondents.

\subsection{Ethnicity}

All the three (3) major ethnic groups in Ghana namely, the Akan (53.1\%), Dagomba (Mole-Dagbani) (18.6\%) and the Ewe (15.6\%) were found along the two wetlands (Table 6) as also found in Kumi et al (2015). However, the Akans had the highest representation among the respondents along Wiwi (75.0\%) and Subin (88.3\%) rivers. This finding is understandable since the two rivers are located among the Ashanti's who form a greater part of the Akan tribe. The finding is supported by literature (Foziah, 2009; Ozesmi and Bauer, 2002; Van Dam et al, 2011; Morrison et al., 2013) that mostly, it is the people from the local community that settle along the wetlands. It will be important to let policy-decision making reflect the ethnicity or the tribe of a particular locality since data on wetlands also need to be multi-scalar (Finlayson and Spiers, 1999).

\subsection{Religion}

The two most practiced religions in Ghana, Christianity $(75.2 \%)$ and Islam (18.6\%) were the only ones practiced at Wiwi $(76.1 \%$ and $23.9 \%$ ) and Subin (88.3\% and $11.7 \%$ ) respectively as shown in Table 7. This finding differs from the study by Kumi et al, (2015) conducted in Accra, Ghana, where African Traditional Religion (ATR) came second with $32 \%$ after Christianity (60\%). For policydecision making, the distribution of religious practices along wetlands, like ethnicity, may be local community biased.

\subsection{Households}

The prevailing modes of household type for the respondents were the tenancy and family house types, and the percentages were Wiwi (44.2\% and 39.8\%) and Subin (76.7\% and 20.6\%) respectively, as shown in Table 8. This differs from both the AR and Ghana where the leading modes were the tenancy (38.3\% and $31.3 \%)$ and the house ownership $(35.1 \%$ and $47.5 \%)$ respectively. This finding suggests that the respondents were not in positions to own houses, so they were mostly renting, though some also stayed in family houses. This phenomenon may also be due to the transient nature of wetland settlers.

\subsection{Length of Stay}

Most of the respondents have been staying along the wetlands for less than five years: $71.2 \%$ at Wiwi and $76.7 \%$ at Subin. This is followed by those who have stayed 11-20 years and 5-10 years as shown in Table 9 . The findings together with the prevailing household modes are important for policy-decision making since they suggest that most wetland settlers stay for a relatively short time ( 5 or less years) and move elsewhere to find jobs and better living. Only those who have been staying there for more than 20 years seem to be permanent.

\subsection{Incomes}


The findings from Table 10 show that $83.7 \%$ and $91.8 \%$ of the respondents at Wiwi and Subin respectively earned Ghç500.00 (\$87.00) or below. This income falls below the average monthly wage of Ghç974 $(\$ 171)$ in Ghana $(G S S, 2019)$ though it is still about the minimum monthly wage figure of Ghç319.00 (\$55.50) (Wagelndicator Foundation, 2020) in the country. The findings suggest that only a few (16.3\% at Wiwi and $8.9 \%$ of Subin) are not poor and have income above average, per the Ghanaian standard. These findings which confirm Infield (1988), Newmark et al. (1993), McGregor (1995), Badola (1997), Ozesmi (1999) and Tyler (2011) that, mostly it is the poor who settle along wetlands to take advantage of their natural resources, are important for policy-decision making

\section{Conclusion}

During the colonial period in Ghana, the area that stretched from the edge of wetlands (rivers and streams) to 300 meters inland were established as green-belts in Kumasi and human settlements were prohibited in those areas. Currently, settlements are evolving along edges of many rivers and streams in Ghana, including the Wiwi and Subin rivers in Kumasi without regard to the green-belts prohibitions, or the damage settlements cause to wetlands. The findings of this study call for the review of existing policies and or enactment of new ones to help protect and manage wetlands sustainably in Ghana. The demographic characteristics of wetland settlers revealed in this study neither favour sustainable management and utilization of wetlands nor socio-economic development, since settlers are mostly poor, without formal education and employment, though mostly young and active. Consequently, the wetlands would be destroyed by the rapidity of the depletion of their natural resources. Though the low incomes and poverty prevalent along wetlands make most wetland settlers transient, another pressing issue that must be confronted is the accumulating presence of the SHS certificate holders who were also found to be young, active, jobless and poor.

\section{Declarations}

- Funding: Not applicable

- Conflict of interest: The authors declare that there is no actual or potential conflict of interest in terms of financial, personal or other relationships with other people or organizations that could inappropriately influence or be perceived to influence this work. The cost of undertaking this research was borne by the authors and as such has no potential of adversely influencing the article's content.

- Availability of data: Not applicable

- Code availability: Not applicable

- Ethics Approval: The ethics of the study protocol was approved by the Architecture Department Review Board, Kwame Nkrumah University of Science and Technology and No human, animal, plant or soil subjects were used for this study. The study involved questionnaire-based survey of residents at wetland sites. Participants provided their verbal informed consent for the survey questions.

- Consent to Participate: All participants included in the questionnaire survey gave verbal informed consent to participate in this research.

- Consent for publication: All participants included in the questionnaire survey gave verbal informed consent to publish the data contained in this article.

- Availability of data and materials: All data produced from this study are provided in the manuscript.

- Authors contribution:

- Victor Kwesi Quagraine: Conceptualisation, Methodology and Editing of Original Manuscript; Literature review and Investigation; Writing - Original Draft Preparation; Writing - Original Draft Preparation and Reviewing and Editing of the Revised Manuscript

- Joy Ofori-Konadu: Conceptualisation; Writing - Original Draft Preparation and Reviewing and Editing of the Revised Manuscript.

- Michael Osei Asibey: Literature review and Investigation; Methodology; Writing - Original Draft Preparation.

\section{References}

Page $7 / 16$ 
1. Abdul-Razak, I. (2012). Assessing the Ecology of Wetlands in Kumasi and the Adaptations of the Communities to Floods. Retrieved from Kwame Nkrumah University of Science and Technology Dissertation Data Base.

2. Adade, R., Nyarko, B. K., Aheto, D. W. and Osei, K. N. (2017). Fragmentation of wetlands in the south eastern coastal savanna of Ghana. Regional Studies in Marine Science, 12, 40-48.

3. Anderson, T. (1998). Wetlands management in Ghana. In Cornerstone of development: integrating environmental, social, and economic policies. IDRC, Ottawa, ON, CA.

4. Armah, A. K. (1993). Coastal wetlands of Ghana. In Coastal Zone'93 (pp. 313-322). ASCE.

5. Asamoah-Gyimah, K. and F. Duodu (2007). Introduction to research methods in education. Winneba: Institute for Educational Development and Extension (IEDE), University of Education, Winneba, Ghana.

6. Asomani-Boateng, R. (2019). Urban wetland planning and management in Ghana: a disappointing implementation. Wetlands, 39(2), 251-261.

7. Attuquayefio, D. K. and Gbogbo, F. (2001). Prospects of conserving wetlands along the Mukwe Lagoon at Nungua in the Greater Accra Region of Ghana. West African Journal of Applied Ecology, 2(1).

8. Badola, R. (1997). Economic assessment of human-forest interrelationship in the forest corridor linking the Rajaji and Corbett National parks. Ph.D. Thesis. Jiwaji University, Gwalior. 220 pp.

9. Bergkamp, G., McCartney, M., Dugan, P., McNeely, J. and Acreman M. (2000) Dams, ecosystem functions and environmental restoration. WCD Thematic Review - Environmental Issues II.1. Final Report to the World Commission on Dams. Secretariat of the World Commission on Dams, Cape Town. 187 pp.

10. Boulé, M.E. (1994). An early history of wetland ecology. In: Global Wetlands: Old World and New, ed. W.J. Mitsch, pp. 57-74. Amsterdam, the Netherlands: Elsevier

11. Cools, J., Johnston, R., Hattermann, F. F., Douven, W., and Zsuffa, I. (2013). Tools for wetland management: Lessons learnt from a comparative assessment. Environmental science \& policy, 34, 138-145.

12. Creswell, J. W. (2002). Educational research: Planning, conducting, and evaluating quantitative and qualitative research. Upper Saddle River, NJ: Pearson Education.

13. Curtin, P. D. (1992). Medical knowledge and urban planning in colonial tropical Africa. The social basis of health and healing in Africa, 235-255.

14. Dahl, T. E. and Allord, G. J. (1982). History of Wetlands in the Conterminous. US geological survey water-supply paper, 19.

15. Dahl, T. E., Johnson, C. E., and Frayer, W. E. (1991). Wetlands, status and trends in the conterminous United States mid1970's to mid-1980's. Washington D.C.: U.S. Fish and Wildlife Service.

16. Davidson, N.C. (2014). How much wetland has the world lost? Long-term and recent trends in global wetland area. Marine and Freshwater Research, 65, 936-941.

17. De Groot, R. S. (1992). Functions of nature: evaluation of nature in environmental planning, management and decision making. Wolters-Noordhoff BV.

18. Dickson, K., and Benneh, G. (1980). A New Geography of Ghana, Metricated Edition 2nd Impression.

19. Ekumah, B., Armah, F. A., Afrifa, E. K., Aheto, D. W., Odoi, J. O. and Afitiri, A. R. (2020). Geospatial assessment of ecosystem health of coastal urban wetlands in Ghana. Ocean \& Coastal Management, 193, 105226.

20. Finlayson, C.M., D'Cruz, R. and Davidson, N.J. (2005). Ecosystem Services and Human Well-being: Water and Wetlands Synthesis. World Resources Institute, Washington DC, USA.

21. Finlayson, C.M. and Spiers, A.G. (Eds.), (1999). Global Review of Wetland Resources and Priorities for Wetland Inventory. Supervising Scientist Report 144. Supervising Scientist, Canberra.

22. Forkuor, D. (2010). Land Allocation and its effects on the spatial planning and development of Kumasi Metropolis (Doctoral dissertation). Retrieved from Kwame Nkrumah University of Science and Technology Dissertation Data Base

23. Foster, J., Barkmann, J., Fricke, R., Hotes, S., Kleyer, M., Kobbe, S., Kubber, D., Rumbaur, C., Siegmund-Schultze, M., Seppelt, R., Settele, J., Tekken, V., Vaclavik, T. and Wit, H. (2015). Assessing Ecosystem services for informing land-use decisions: a problemoriented approach. Ecology and Society, 20(3), 31. 
24. Foziah, H. (2009). A Study on Waterfowl Population and Human Use of Hokersar and Hygam Wetlands of Kashmir Valley for Conservation Planning (Doctoral dissertation, Saurashtra University).

25. Fretwell, J. D., Williams, J. S. and Redman, P. J. (1996). National water summary on wetland resources. U.S. Geological Environ Monit Assess (2019) 191(Suppl 1): 324 Page 21 of 23324 Survey Water-supply paper 2425. Washington, D.C.: U.S. Government Printing Office.

26. Ghana Hydrological Department (2006). Map of Kumasi. https://www.sciencedirect.com/science/article/abs/pii/S014362281630830X. Accessed 2 November 2020

27. Ghana Permanent Mission to United Nations (2021). Map and Regions in Ghana. https://www.ghanamissionun.org/mapregions-in-ghana/. Accessed 26 January 2021

28. Ghana Statistical Service (GSS) (2012). 2010 Population and housing census: summary report of final results. Ghana Statistical Service Accra.

29. Ghana Statistical Service (GSS) (2014). 2010 Population and housing census: district analytical report, Kumasi metropolis. Ghana Statistical Service Accra.

30. Ghana Statistical Service (GSS) (2019). Ghana Living Standards Survey (GLSS) 7, Main Report. Ghana Statistical Service Accra. https://www.statsghana.gov.gh/gssmain/fileUpload/pressrelease/GLSS7\%20MAIN\%20REPORT_FINAL.pdf. Accessed 22 November 2020

31. Government of Ghana (GoG) (1994). Environmental Action Plan. Marine and Coastal Ecosystem. Govt of Ghana, Accra, Ghana. Vol II 79-116.

32. Gumma, M., Thenkabail, P. S., Fujii, H. and Namara, R. (2009). Spatial models for selecting the most suitable areas of rice cultivation in the Inland Valley Wetlands of Ghana using remote sensing and geographic information systems. Journal of Applied Remote Sensing, 3(1), 033537.

33. Hachigonta, S., Nelson, G. C., Thomas, T. S. and Sibanda, L. M. (eds) (2013). Southern African Agriculture and Climate Changea comprehensive analysis. International Food Policy Research Institute, Washington DC. doi:http://dx. doi.org/10.2499/9780896292086

34. Hammerton, D. (1972). The Nile river - a case study. In: River Ecology and Man, ed. R.T. Oglesby, C.A. Carlson \& M.J. McCann, pp. 71-214. New York, USA: Academic Press

35. Hu, S., Niu, Z., Chen, Y., Li, L. and Zhang, H. (2017). Global wetlands: Potential distribution, wetland loss, and status. Science of the Total Environment, 586, 319-327.

36. Infield, M. (1988). Attitudes of a rural community towards conservation and a local conservation area in Natal, South Africa. Biological conservation, 45(1), 21-46.

37. Jacob, A. L., Bonnell, T. R., Dowhaniuk, N. and Hartter, J. (2014). Topographic and spectral data resolve land cover misclassification to distinguish and monitor wetlands in western Uganda. ISPRS journal of photogrammetry and remote sensing, 94, 114-126.

38. Johnston, C. A. (1994). Cumulative impacts to wetlands. Wetlands, 14(1), 49-55.

39. Junk, W. J. (2002). Long-term environmental trends and the future of tropical wetlands. Environmental conservation, 414-435.

40. Kabii, T. (1996). An overview of African wetlands. https://www.oceandocs.org/bitstream/handle/1834/457/Africa_? sequence $=1$. Accessed 15 February 2021

41. Kent, D. M. (2000). Evaluating wetland functions and values. KENT D M. Applied Wetland Science and Technology. 2nd ed. New York: Lewis Publishers, 55-80.

42. Kingsford, R. T., Basset, A. and Jackson, L. (2016). Wetlands: conservation's poor cousins. Aquatic Conservation: Marine and Freshwater Ecosystems, 26(5), 892-916.

43. Koohafkan, P., Nachtergaele, F. and Antoine, J. (1998). Use of agro-ecological zones and resource management domains for sustainable management of African wetlands. Wetland Characterization and Classification for Sustainable Agricultural Development. Harare, Zimbabwe: FAO/SAFR.

44. Kooijmans, L. L. (1987). Neolithic settlement and subsistence in the wetlands of the Rhine/Meuse delta of the Netherlands. European wetlands in prehistory, 227-251. 
45. Kumi, J., Kumi, M. and Apraku, A. (2015). Threats to the conservation of wetlands in Ghana: the case of Songor Ramsar site. Journal of Scientific Research and Reports, 6(1), 13-25.

46. Lomnicky, G. A., Herlihy, A. T. and Kaufmann, P. R. (2019). Quantifying the extent of human disturbance activities and anthropogenic stressors in wetlands across the conterminous United States: results from the National Wetland Condition Assessment. Environmental monitoring and assessment, 191(1), 1-23.

47. Maclean, I. M., Boar, R. R. and Lugo, C. (2011). A review of the relative merits of conserving, using, or draining papyrus swamps. Environmental management, 47(2), 218-229.

48. Mafabi, P. (2000). The role of wetland policies in the conservation of waterbirds: the case of Uganda. Ostrich, 71(1-2), 96-98.

49. Martinez-Harms, M. J., Bryan, B, A., Balvanera, E. A., Law, E. A., Rhodes, J. R., Possingham, H. P. and Wilsona, K. A. (2015). Making decisions for managing ecosystem services. Biological Conservation 184, 229-238.

50. Matthew E. and Fung X. (1987). Natural wetlands. NASA/Goddard Institute of Space Studies (GISS), Columbia University, New York, USA.

51. McGregor, J. (1995). Gathered produce in Zimbabwe's communal areas changing resource availability and use. Ecology of Food and Nutrition, 33(3), 163-193.

52. Millennium Ecosystem Assessment (2005). Ecosystems and human well-being: wetlands and water. World Resources Institute.

53. Ministry of Lands and Forestry (1999). Managing Ghana's wetlands: a national wetlands conservation strategy, vol. 1999. Accra

54. Mitsch, W. J. and Gosselink, J. G. (2000). The value of wetlands: importance of scale and landscape setting. Ecological economics, 35(1), 25-33.

55. Mitsch, W. and Gosselink, J. (2007). Wetland. John Willey \& Sons: Hoboken, NJ, USA, pp. 287-288.

56. Morrison, E. H., Upton, C., Pacini, N., Odhiambo-K'oyooh, K. and Harper, D. M. (2013). Public perceptions of papyrus: community appraisal of wetland ecosystem services at Lake Naivasha, Kenya. Ecohydrology \& Hydrobiology, 13(2), 135-147.

57. Newmark, W. D., Leonard, N. L., Sariko, H. I. and Gamassa, D. G. M. (1993). Conservation attitudes of local people living adjacent to five protected areas in Tanzania. Biological conservation, 63(2), 177-183.

58. Nicholls, R.J. (2004). Coastal flooding and wetland loss in the 21st century: Changes under the SRES climate and socioeconomic scenarios. Global Environmental Change. 14, 69-86.

59. Nimura, A. and Eisen, S. (2010). Gender needs assessment for Kumasi, Ghana.http://mci.ei.columbia.edu/files/2012/12/Kumasi-Gender-Needs-Assessment.pdf. Accessed 2 December 2020

60. Nsor, C. A. and Obodai, E. A. (2014). Environmental determinants influencing seasonal variations of bird diversity and abundance in Wetlands, Northern Region (Ghana). International Journal of Zoology, 2014.

61. Nyarko, B. K. (2007). Floodplain Wetland River Flow Synergy in the White Volta Rivver Basin, Ghana. ZEF.

62. Obiri-Danso, K., Weobong, C. A. A. and Jones, K. (2005). Aspects of health-related microbiology of the Subin, an urban river in Kumasi, Ghana. Journal of Water and health, 3(1), 69-76.

63. Opoku, J. A. (2013). Effects of human encroachment on Wetlands in Ghana: The case of Sakumono Ramsar site (Doctoral dissertation, University of Cape Coast).

64. Owino, A. O. and Ryan, P. G. (2007). Recent papyrus swamp habitat loss and conservation implications in western Kenya. Wetlands Ecology and management, 15(1), 1-12.

65. Owusu-Ansah, J. K. (2016). The influences of land use and sanitation infrastructure on flooding in Kumasi, Ghana. GeoJournal, 81(4), 555-570.

66. Ozesmi, V. (1999). Conservation Strategies for Sustainable Resource Use in the Kizilirmak Delta, Turkey. Ph.D.Thesis. University of Minnesota.

67. Ozesmi, S. L. and Bauer, M. E. (2002). Satellite remote sensing of wetlands. Wetlands ecology and management 10 (5): $381-402$.

68. Patrick Jr, W. H. (1994). From wastelands to wetlands. Journal of Environmental Quality, 23(5), 892-896.

69. Pattison, J., Boxall, P. C., and Adamowicz, W. L. (2011). The economic benefits of wetland retention and restoration in Manitoba. Canadian Journal of Agricultural Economics/Revue canadienne d'agroeconomie, 59(2), 223-244.

70. Quagraine, V. K. (2011). Urban Landscape Depletion in the Kumasi Metropolis: In K.K. Adarkwa, (Ed.), Future of the Tree: Towards growth and development of Kumasi. University Printing Press, KNUST, pp. 226-227.

Page 10/16 
71. Quevauviller, P. (Ed.) (2009). Water System Science and Policy Interfacing. The Royal Society of Chemistry, Cambridge, ISBN: 978-1-84755-861-9.

72. Ramsar Convention (1971). The Ramsar Convention. Ramsar Center, Rue Mauverney 28, CH 1196, Gland, Switzerland.

73. Ramsar Convention on Wetlands (2018). Scaling up Wetland Conservation, Wise Use and Restoration to Achieve the Sustainable Development Goals. Available online: https://www.ramsar.org/sites/default/files/ documents/library/wetlands_sdgs_e.pdf

74. Rebelo, L. M., Finlayson, C. M., and Nagabhatla, N. (2009). Remote sensing and GIS for wetland inventory, mapping and change analysis. Journal of environmental management, 90(7), 2144-2153.

75. Rebelo, L. M., McCartney, M. P. and Finlayson C. M. (2010). Wetlands of sub-saharan Africa: distribution and contribution of agriculture to livelihoods. Wetlands Ecology and Management 18:557-572.

76. Republic of Ghana (1999). National land policy. Ministry of Lands and Forestry. http://www.rspo-inghana.org/sitescene/custom/userfiles/file/NATIONAL_LAND_POLICY_.pdf. Accessed 1 October 2020

77. Roggeri, H. (1995). Tropical freshwater wetlands: a guide to current knowledge and management, Kluwer Academic Publishers.

78. Root, T.L., Price, J.T., Hall, K.R., Schneider, S.H., Rosenzweig, C. and Pounds, J.A. (2003). Fingerprints of global warming on wild animals and plants. Nature, 421, 57-60.

79. Ryan, J. M., and Ntiamoa-Baidu, Y. (2000). Biodiversity and ecology of coastal wetlands in Ghana. ugspace.ug.edu.gh

80. Šabić, D., Miljković, O., Vujadinović, S., Milinčić, M. and Gajić, M. (2013). Geo-ecological transformation of wetland into agricultural landscape: the case of Pančevački Rit, Serbia. Journal of Environmental Protection and Ecology, 14(2), 517-523.

81. Sah, J. P., and Heinen, J. T. (2001). Wetland resource use and conservation attitudes among indigenous and migrant peoples in Ghodaghodi Lake area, Nepal. Environmental conservation, 345-356.

82. Schuijt, K. (2002). Land and water use of wetlands in Africa: economic values of African wetlands. pure.iiasa.ac.at

83. Schuyt, K. D. (2005). Economic consequences of wetland degradation for local populations in Africa. Ecological economics, 53(2), 177-190.

84. Stone R. (2003). Freshwater eels are slip-sliding away. Science 302: 221.

85. Tebeau, C. W. (1980). A history of Florida: Coral Gables. Fla. University of Miami Press, p.527.

86. Tyler, R. (2011). Incorporating local participation and GIS in assessing flood vulnerability in informal settlements: Masiphumelele case study (Master's thesis, University of Cape Town).

87. van Dam, A., Kipkemboi, J., Zaal, F. and Okeyo-Owuor, J. B. (2011). The ecology of livelihoods in East African papyrus wetlands (ECOLIVE). Reviews in Environmental Science and Bio/Technology, 10(4), 291-300.

88. Wagelndicator Foundation (2020). Minimum Wage -Ghana. https://mywage.org/ghana/salary/minimum-wages. Accessed 20 March 2021

89. Wang, H. and Ma, M. (2016). Impacts of climate change and anthropogenic activities on the ecological restoration of wetlands in the arid regions of China. Energies, 9(3), 166.

90. Wetlands International (2005). Ramsar Sites: Directory and Overview, eighth ed. Wetlands International.

91. Wood, A., Dixon, A. and McCartney, M. (eds) (2013). Wetland man- agement and sustainable livelihoods in Africa. Routledge, London/New York

92. World Conservation Monitoring Centre (WCMC) (1992). Global Biodiversity: Status of the Earth's Living Resources. London: Chapman \& Hall.

93. World Weather Online (2019). 'Kumasi Monthly Climate Averages' https://www.worldweatheronline.com/kumasi-weatheraverages/ashanti/gh.aspx. Accessed 8 December 2020.

94. Zedler, J. B. and Kercher, S. (2005). Wetland resources: status, trends, ecosystem services, and restorability. Annu. Rev. Environ. Resour., 30, 39-74.

\section{Tables}

Table 1: Gender Distribution

Page $11 / 16$ 


\begin{tabular}{|lllllllll|}
\hline Gender & $\begin{array}{l}\text { Frequency } \\
\text { (Wiwi) }\end{array}$ & $\begin{array}{l}\text { Frequency } \\
\text { (Subin) }\end{array}$ & $\begin{array}{l}\text { Frequency } \\
\text { (Ashanti } \\
\text { Region) }\end{array}$ & $\begin{array}{l}\text { Frequency } \\
\text { (Ghana) }\end{array}$ & $\begin{array}{l}\text { Percentage } \\
\text { (Wiwi) }\end{array}$ & $\begin{array}{l}\text { Percentage } \\
\text { (Subin) }\end{array}$ & $\begin{array}{l}\text { Percentage } \\
\text { (Ashanti } \\
\text { Region) }\end{array}$ & $\begin{array}{l}\text { Percentage } \\
\text { (Ghana) }\end{array}$ \\
\hline Male & 61 & 74 & $2,316,052$ & $12,024,845$ & $44.2 \%$ & $41.1 \%$ & $48.4 \%$ & $48.9 \%$ \\
\hline
\end{tabular}

Table 2: Age Distribution

\begin{tabular}{|lllllllll|}
\hline Age & $\begin{array}{l}\text { Frequency } \\
\text { (Wiwi) }\end{array}$ & $\begin{array}{l}\text { Frequency } \\
\text { (Subin) }\end{array}$ & $\begin{array}{l}\text { Frequency } \\
\text { (Ashanti } \\
\text { Region) }\end{array}$ & $\begin{array}{l}\text { Frequency } \\
\text { (Ghana) }\end{array}$ & $\begin{array}{l}\text { Percentage } \\
\text { (Wiwi) }\end{array}$ & $\begin{array}{l}\text { Percentage } \\
\text { (Subin) }\end{array}$ & $\begin{array}{l}\text { Percentage } \\
\text { (Ashanti } \\
\text { Region) }\end{array}$ & $\begin{array}{l}\text { Percentage } \\
\text { (Ghana) }\end{array}$ \\
\hline $20 \mathrm{~s}$ & 33 & 17 & 886,687 & $4,373,602$ & $23.9 \%$ & $9.3 \%$ & $36.0 \%$ & $34.7 \%$ \\
\hline $30 \mathrm{~s}$ & 28 & 32 & 619,861 & $3,100,212$ & $20.3 \%$ & $17.6 \%$ & $25.2 \%$ & $24.6 \%$ \\
\hline $40 \mathrm{~s}$ & 55 & 111 & 411054 & $2,124,448$ & $40.0 \%$ & $61.6 \%$ & $16.7 \%$ & $16.9 \%$ \\
\hline $50 \mathrm{~s}$ & 11 & 21 & 257,366 & $1,356,793$ & $7.9 \%$ & $11.5 \%$ & $10.5 \%$ & $10.8 \%$ \\
\hline $\begin{array}{l}60 \text { s and } \\
\text { above }\end{array}$ & 11 & - & 286,691 & $1,643,381$ & $7.9 \%$ & - & $11.6 \%$ & $13.0 \%$ \\
\hline
\end{tabular}

Table 3: Educational Background

\begin{tabular}{|lllllllll|}
\hline $\begin{array}{l}\text { Highest } \\
\text { Education }\end{array}$ & $\begin{array}{l}\text { Frequency } \\
\text { (Wiwi) }\end{array}$ & $\begin{array}{l}\text { Frequency } \\
\text { (Subin) }\end{array}$ & $\begin{array}{l}\text { Frequency } \\
\text { (Ashanti } \\
\text { Region) }\end{array}$ & $\begin{array}{l}\text { Frequency } \\
\text { (Ghana) }\end{array}$ & $\begin{array}{l}\text { Percentage } \\
\text { (Wiwi) }\end{array}$ & $\begin{array}{l}\text { Percentage } \\
\text { (Subin) }\end{array}$ & $\begin{array}{l}\text { Percentage } \\
\text { (Ashanti } \\
\text { Region) }\end{array}$ & $\begin{array}{l}\text { Percentage } \\
\text { (Ghana) }\end{array}$ \\
\hline Primary & 22 & 37 & $1,094,173$ & $5,615,573$ & $15.9 \%$ & $20.6 \%$ & $39.1 \%$ & $44.2 \%$ \\
\hline $\begin{array}{l}\text { JHS/Middle } \\
\text { School }\end{array}$ & 11 & 5 & 933,518 & $4,048,059$ & $8.0 \%$ & $2.8 \%$ & $33.4 \%$ & $31.8 \%$ \\
\hline SHS & 55 & 37 & 512,133 & $1,756,714$ & $39.9 \%$ & $21.0 \%$ & $18.3 \%$ & $13.8 \%$ \\
\hline Tertiary & 6 & 5 & 194,097 & 927,017 & $4.3 \%$ & $2.8 \%$ & $7.0 \%$ & $7.3 \%$ \\
\hline $\begin{array}{l}\text { No formal } \\
\text { Education }\end{array}$ & 44 & 95 & 61,047 & 369,365 & $31.9 \%$ & $52.8 \%$ & $2.2 \%$ & $2.9 \%$ \\
\hline
\end{tabular}

Table 4: Occupation

\begin{tabular}{|c|c|c|c|c|c|c|c|c|}
\hline Occupation & $\begin{array}{l}\text { Frequency } \\
\text { (Wiwi) }\end{array}$ & $\begin{array}{l}\text { Frequency } \\
\text { (Subin) }\end{array}$ & $\begin{array}{l}\text { Frequency } \\
\text { (Ashanti } \\
\text { Region) }\end{array}$ & $\begin{array}{l}\text { Frequency } \\
\text { (Ghana) }\end{array}$ & $\begin{array}{l}\text { Percentage } \\
\text { (Wiwi) }\end{array}$ & $\begin{array}{l}\text { Percentage } \\
\text { (Subin) }\end{array}$ & $\begin{array}{l}\text { Percentage } \\
\text { (Ashanti } \\
\text { Region) }\end{array}$ & $\begin{array}{l}\text { Percentage } \\
\text { (Ghana) }\end{array}$ \\
\hline $\begin{array}{l}\text { Public/Civil } \\
\text { servant }\end{array}$ & 11 & 17 & 129,783 & 655,884 & $8.0 \%$ & $9.0 \%$ & $7.3 \%$ & $7.3 \%$ \\
\hline $\begin{array}{l}\text { Entrepreneur/ } \\
\text { Self employed }\end{array}$ & 55 & 69 & $1,298,921$ & $6,791,570$ & $39.9 \%$ & $38.0 \%$ & $73.3 \%$ & $75.4 \%$ \\
\hline Students & 17 & 11 & 261,145 & $1,226,077$ & $12.3 \%$ & $6.0 \%$ & $14.7 \%$ & $13.6 \%$ \\
\hline Unemployed & 33 & 85 & 80,160 & 320,852 & $23.9 \%$ & $47.0 \%$ & $4.5 \%$ & $3.6 \%$ \\
\hline Others & 22 & - & 2,775 & 17,666 & $15.9 \%$ & - & $0.2 \%$ & $0.1 \%$ \\
\hline
\end{tabular}

Table 5: Marital Status 


\begin{tabular}{|lllllllll|}
\hline $\begin{array}{l}\text { Marital } \\
\text { Status }\end{array}$ & $\begin{array}{l}\text { Frequency } \\
\text { (Wiwi) }\end{array}$ & $\begin{array}{l}\text { Frequency } \\
\text { (Subin) }\end{array}$ & $\begin{array}{l}\text { Frequency } \\
\text { (Ashanti } \\
\text { Region) }\end{array}$ & $\begin{array}{l}\text { Frequency } \\
\text { (Ghana) }\end{array}$ & $\begin{array}{l}\text { Percentage } \\
\text { (Wiwi) }\end{array}$ & $\begin{array}{l}\text { Percentage } \\
\text { (Subin) }\end{array}$ & $\begin{array}{l}\text { Percentage } \\
\text { (Ashanti } \\
\text { Region) }\end{array}$ & $\begin{array}{l}\text { Percentage } \\
\text { (Ghana) }\end{array}$ \\
\hline Married & 110 & 127 & $1,271,348$ & $7,061,627$ & $79.7 \%$ & $70.5 \%$ & $51.9 \%$ & $55.1 \%$ \\
\hline Single & 28 & 48 & 852,003 & $4,039,724$ & $20.3 \%$ & $26.7 \%$ & $34.8 \%$ & $31.5 \%$ \\
\hline Divorced & - & - & 124,406 & 573,235 & - & - & $5.1 \%$ & $4.5 \%$ \\
\hline Separated & - & - & 56,709 & 314,487 & - & - & $2.3 \%$ & $2.5 \%$ \\
\hline $\begin{array}{l}\text { Other } \\
\text { (Widow) }\end{array}$ & 5 & 145,525 & 822,593 & & $2.8 \%$ & $5.9 \%$ & $6.4 \%$ \\
\hline
\end{tabular}

Table 6: Ethnicity

\begin{tabular}{|c|c|c|c|c|c|c|c|c|}
\hline Ethnicity & $\begin{array}{l}\text { Frequency } \\
\text { (Wiwi) }\end{array}$ & $\begin{array}{l}\text { Frequency } \\
\text { (Subin) }\end{array}$ & $\begin{array}{l}\text { Frequency } \\
\text { (Ashanti } \\
\text { Region) }\end{array}$ & $\begin{array}{l}\text { Frequency } \\
\text { (Ghana) }\end{array}$ & $\begin{array}{l}\text { Percentage } \\
\text { (Wiwi) }\end{array}$ & $\begin{array}{l}\text { Percentage } \\
\text { (Subin) }\end{array}$ & $\begin{array}{l}\text { Percentage } \\
\text { (Ashanti } \\
\text { Region) }\end{array}$ & $\begin{array}{l}\text { Percentage } \\
\text { (Ghana) }\end{array}$ \\
\hline Akan & 104 & 159 & $3,449,358$ & $11,321,568$ & $75.0 \%$ & $88.3 \%$ & $79.3 \%$ & $53.1 \%$ \\
\hline $\mathrm{Ga}$ & - & - & 54,968 & $1,766,287$ & - & - & $1.3 \%$ & $8.3 \%$ \\
\hline Ewe & 6 & 5 & 175,456 & $3,327,072$ & $4.3 \%$ & $2.8 \%$ & $4.0 \%$ & $15.6 \%$ \\
\hline Hausa & - & - & & & - & - & & \\
\hline $\begin{array}{l}\text { Mamprusi } \\
\text { (Grusi) }\end{array}$ & 17 & 5 & 94,509 & 594,248 & $12.1 \%$ & - & $2.2 \%$ & $2.8 \%$ \\
\hline $\begin{array}{l}\text { Dagomba } \\
\text { (Mole- } \\
\text { Dagbani) }\end{array}$ & 6 & 11 & 525,742 & $3,963,017$ & $4.3 \%$ & $6.1 \%$ & $12.0 \%$ & $18.6 \%$ \\
\hline Other & 5 & 48 & 50,014 & 342,197 & $4.3 \%$ & $2.8 \%$ & $1.2 \%$ & $1.6 \%$ \\
\hline
\end{tabular}

Table 7: Ethnicity

\begin{tabular}{|lllllllll|}
\hline Religion & $\begin{array}{l}\text { Frequency } \\
\text { (Wiwi) }\end{array}$ & $\begin{array}{l}\text { Frequency } \\
\text { (Subin) }\end{array}$ & $\begin{array}{l}\text { Frequency } \\
\text { (Ashanti } \\
\text { Region) }\end{array}$ & $\begin{array}{l}\text { Frequency } \\
\text { (Ghana) }\end{array}$ & $\begin{array}{l}\text { Percentage } \\
\text { (Wiwi) }\end{array}$ & $\begin{array}{l}\text { Percentage } \\
\text { (Subin) }\end{array}$ & $\begin{array}{l}\text { Percentage } \\
\text { (Ashanti } \\
\text { Region) }\end{array}$ & $\begin{array}{l}\text { Percentage } \\
\text { (Ghana) }\end{array}$ \\
\hline Christianity & 105 & 159 & $3,719,793$ & $17,546,837$ & $76.1 \%$ & $88.3 \%$ & $82.3 \%$ & $75.2 \%$ \\
\hline Islam & 33 & 21 & 728,741 & $4,345,723$ & $23.9 \%$ & $11.7 \%$ & $16.1 \%$ & $18.6 \%$ \\
\hline Traditionalist & - & - & 34,685 & $1,270,272$ & - & - & $0.8 \%$ & $5.4 \%$ \\
\hline Other & - & - & 37,172 & 193,914 & - & - & $0.8 \%$ & $0.8 \%$ \\
\hline
\end{tabular}

Table 8: Household 


\begin{tabular}{|lllllllll|}
\hline $\begin{array}{l}\text { Type of } \\
\text { Household }\end{array}$ & $\begin{array}{l}\text { Frequency } \\
\text { (Wiwi) }\end{array}$ & $\begin{array}{l}\text { Frequency } \\
\text { (Subin) }\end{array}$ & $\begin{array}{l}\text { Frequency } \\
\text { (Ashanti } \\
\text { Region) }\end{array}$ & $\begin{array}{l}\text { Frequency } \\
\text { (Ghana) }\end{array}$ & $\begin{array}{l}\text { Percentage } \\
\text { (Wiwi) }\end{array}$ & $\begin{array}{l}\text { Percentage } \\
\text { (Subin) }\end{array}$ & $\begin{array}{l}\text { Percentage } \\
\text { (Ashanti } \\
\text { Region) }\end{array}$ & $\begin{array}{l}\text { Percentage } \\
(\text { Ghana) }\end{array}$ \\
\hline Tenant & 61 & 138 & 428,376 & $1,699,250$ & $44.2 \%$ & $76.7 \%$ & $38.3 \%$ & $31.3 \%$ \\
\hline Owner & 22 & 5 & 392,626 & $2,579,493$ & $16.0 \%$ & $2.7 \%$ & $35.1 \%$ & $47.5 \%$ \\
\hline $\begin{array}{l}\text { Family } \\
\text { house }\end{array}$ & 55 & 37 & 295,663 & $1,138,097$ & $39.8 \%$ & $20.6 \%$ & $26.4 \%$ & $21.0 \%$ \\
\hline Other & - & - & 1288 & 9,806 & - & - & $0.1 \%$ & $0.2 \%$ \\
\hline
\end{tabular}

Table 9: Length of Stay

\begin{tabular}{|lllllllll|}
\hline $\begin{array}{l}\text { Years of } \\
\text { Stay }\end{array}$ & $\begin{array}{l}\text { Frequency } \\
\text { (Wiwi) }\end{array}$ & $\begin{array}{l}\text { Frequency } \\
\text { (Subin) }\end{array}$ & $\begin{array}{l}\text { Frequency } \\
\text { (Ashanti } \\
\text { Region) }\end{array}$ & $\begin{array}{l}\text { Frequency } \\
\text { (Ghana) }\end{array}$ & $\begin{array}{l}\text { Percentage } \\
\text { (Wiwi) }\end{array}$ & $\begin{array}{l}\text { Percentage } \\
\text { (Subin) }\end{array}$ & $\begin{array}{l}\text { Percentage } \\
\text { (Ashanti } \\
\text { Region) }\end{array}$ & $\begin{array}{l}\text { Percentage } \\
\text { (Ghana) }\end{array}$ \\
\hline $\begin{array}{l}\text { Below } 5 \\
\text { years }\end{array}$ & 99 & 138 & - & - & $71.2 \%$ & $76.7 \%$ & - & - \\
\hline $\begin{array}{l}5-10 \\
\text { years }\end{array}$ & 6 & 16 & - & - & $4.3 \%$ & $8.9 \%$ & - & - \\
\hline $\begin{array}{l}11-20 \\
\text { years }\end{array}$ & 6 & 5 & - & - & $4.3 \%$ & $2.7 \%$ & - & - \\
\hline $\begin{array}{l}\text { Above } 20 \\
\text { years }\end{array}$ & 28 & 21 & - & - & $20.2 \%$ & $11.7 \%$ & - & - \\
\hline
\end{tabular}

Table 10: Income Distribution

\begin{tabular}{|lllllllll|}
\hline Income group & $\begin{array}{l}\text { Frequency } \\
\text { (Wiwi) }\end{array}$ & $\begin{array}{l}\text { Frequency } \\
\text { (Subin) }\end{array}$ & $\begin{array}{l}\text { Frequency } \\
\text { (Ashanti } \\
\text { Region) }\end{array}$ & $\begin{array}{l}\text { Frequency } \\
\text { (Ghana) }\end{array}$ & $\begin{array}{l}\text { Percentage } \\
\text { (Wiwi) }\end{array}$ & $\begin{array}{l}\text { Percentage } \\
\text { (Subin) }\end{array}$ & $\begin{array}{l}\text { Percentage } \\
\text { (Ashanti } \\
\text { Region) }\end{array}$ & $\begin{array}{l}\text { Percentage } \\
\text { (Ghana) }\end{array}$ \\
\hline Below Ghç 500 & 116 & 164 & - & - & $83.7 \%$ & $91.8 \%$ & - & - \\
\hline $501-1000$ & 17 & 16 & - & - & $12.0 \%$ & $8.9 \%$ & - & - \\
\hline $1101-2000$ & 6 & - & - & - & $4.3 \%$ & - & - & - \\
\hline Above 2001 & - & - & - & - & - & - & - & - \\
\hline
\end{tabular}

\section{Figures}




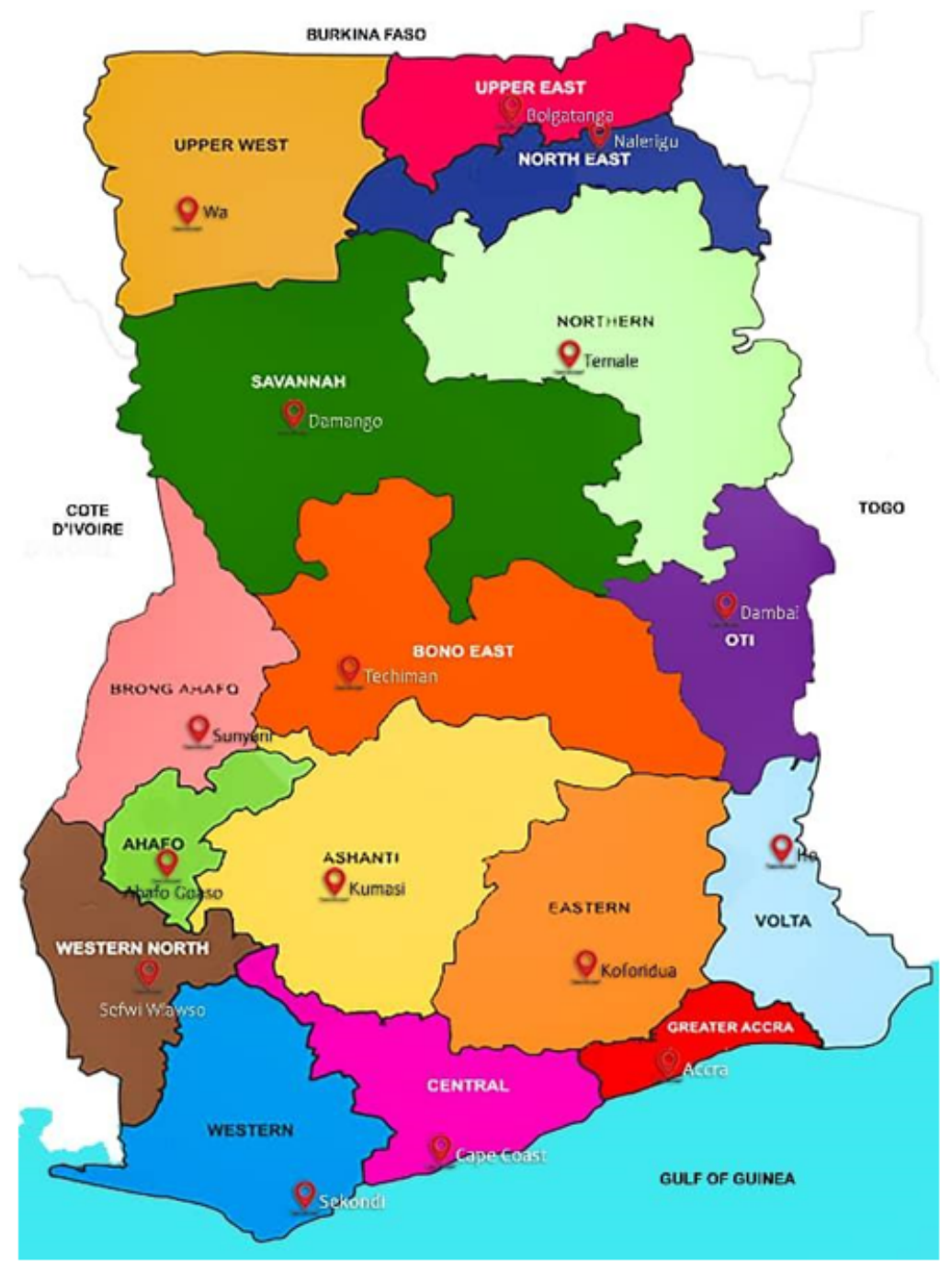

Figure 1

Map of Ghana with its sixteen (16) regions (Source: Adapted from Ghana Permanent Mission to United Nations, 2021). 


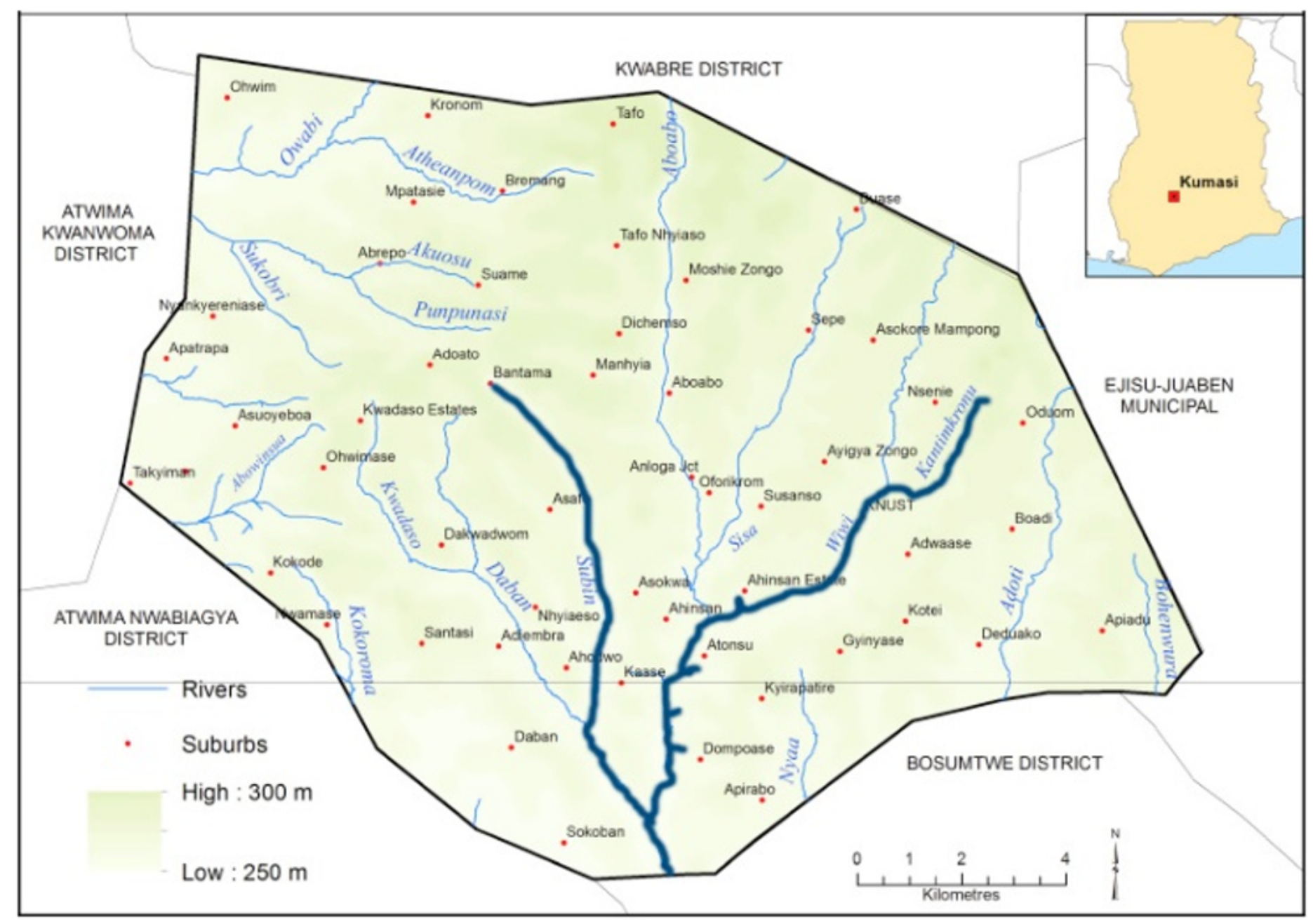

Figure 2

Rivers and streams (wetlands) in Kumasi (Source: Ghana Hydrological Department, 2006). 